\title{
A CRITICAL THINKING APPROACH FOR IMPLEMENTING INTERDISCIPLINARITY IN CAREER GUIDANCE FOR SECONDARY SCHOOL STUDENTS
}

\author{
Gunars Strods $^{1}$, Aina Strode ${ }^{2}$
}

\begin{abstract}
Skills that promote the growth and well-being of society are particularly important. In this context an important task is to encourage more young people to choose professions in mathematics, science and technology, as the adequacy of the number of graduates in these highly sought after fields is extremely important for innovation and growth.

In the context of Latvia, Lithuania and Estonia, the fields of Wood-Forestry, Metal-Machinery, and Agriculture-Food are considered to be fast-growing industries. However, the number of trained specialists is insufficient, and the motivation and interest of potential employees should be facilitated by school career counselors.

The aim of this article is to study the most demanded professional competencies in Wood-Forestry, Metal-Machinery, and the Agriculture-Food industries and to elaborate recommendations for designing a methodology for career counselor's professional development training for career guidance in secondary school.

Research methods: A literature study and a questionnaire. In total 130 respondents - Administrative, Sector managers and Sector specialists from companies, voluntary answered the survey questions online.

The results of the study determined the most demanded competencies in Wood-Forestry, Metal-Machinery and the Agriculture-Food industries are related to design, technology and economics. It is recommended to use a critical thinking approach for implement interdisciplinarity in career guidance in secondary schools. The career counselors should be introduced to the most demanded professional competencies in Wood-Forestry, Metal-Machinery, and Agriculture-Food industries during professional development training for career guidance for secondary school students.
\end{abstract}

UDC Classification: 37.01/.09, 37.02; DOI: http://dx.doi.org/10.12955/cbup.v6.1251

Keywords: career education, career guidance, interdisciplinarity, critical thinking.

\section{Introduction}

At the national and EU level, a major issue of the debate on education policy is the adaptation of the European education and training system to the needs of today's economies and societies. Skills that promote growth and well-being are particularly important. In this context, the European Commission has published a report: "Rethinking Education: Investing in skills for better socio-economic outcomes" (2012). In response to the new social, economic and technological situations, the communication called for renewed vigor to address the challenges of the 21 st century, promote open and flexible learning, and prioritize investment in education and training.

Another major challenge is the need for further integration of cross-sectoral skills (e.g. ICT, entrepreneurship and civic skills) into teaching and learning. An important task is to encourage more young people to choose a profession in mathematics, science and technology, as the adequacy of the number of graduates in these highly sought after fields is extremely important for innovation and growth.

In the context of Latvia, Lithuania and Estonia, the fields of Wood-Forestry, Metal-Machinery, and Agriculture-Food are considered to be fast-growing industries. However, the number of trained specialists is insufficient, and the motivation and interest of potential employees should be facilitated by school career counselors. Since the education in schools mostly implemented by women who are not familiar with the specifics of technical professions, there is need to prepare methodological materials based on the study of professions standards. In this way, interdisciplinarity will be provided, enabling students to apply their knowledge in studying and learning professions.

The aim of this article is to study the most demanded professional competencies in the Wood-Forestry, Metal-Machinery, and Agriculture-Food industries and elaborate recommendations for designing a methodology for the professional development training of career counselors on career guidance in secondary school.

The study was conducted within the framework of Erasmus + Strategic Partnership Project Implementing Interdisciplinarity in Career Counseling No.016-1-LV01-KA201-022681.

\footnotetext{
${ }^{1}$ Faculty of Education, Languages and Design, Rezekne Academy of Technologies, Latvia, gunars.strods@rta.lv

${ }^{2}$ Faculty of Education, Languages and Design, Rezekne Academy of Technologies, Latvia, aina.strode@
} 


\section{Theoretical background}

Career education is the planned provision of events, courses and programs at educational institutions to help learners develop skills for mapping their interests, abilities and opportunities, setting their career goals and career management. It provides knowledge and understanding of the world of work, its link with education, career planning and further education opportunities and ensures effective participation in one's working life (Career Education at School, 2010).

A modern, competitive economy requires employees who have the skills, knowledge and attitudes that can be used in any work situation and who have the ability and desire to continuously adapt and succeed in a changing world. Therefore, skills relevant employment are an essential part of career management skills. Employment skills are defined as "the set of qualities, skills and knowledge that is needed by every participant in the labor market to ensure their effectiveness in the workplace - for their own growth, for their employer and for the economy of the country as a whole" (Kenneth, 2001). When it comes to the professions of technical disciplines, it is important to recognize the set of skills needed - the specific, technical and general work skills that are partly recognized and learned in general education, such as subjects of design, technology and economics.

The topicality of the interdisciplinary approach in today's world determines the required values:

- The ability to operate independently and at the same time be able to work in multidisciplinary teams;

- The ability to perceive thoughts, things, phenomena which may look completely different and to unite them into common, new forms.

The task of career education - to shift from a mono-individual proposition view to strengthening the readiness of a complex world-wide solution of today's issues by creating a new "open dialogue" relationship between education and industry.

Interdisciplinarity - extending the boundaries of the existing fields by applying and using epistemology (a method of knowledge acquisition) methodology, canons, and pedagogical techniques of other areas. The benefits of interdisciplinarity, combined with epistemology and the use of different research areas can reveal new aspects that could not have been foreseen in the past (Collin, 2009; Boden, 2004). The principles of interdisciplinarity are consistent with the constructivist view of the multidimensional problem views and solutions. A constructivist approach is perceived by human activity as a base in the creation and design of knowledge. The learning process focused on mental development involves four guiding and interrelated elements (David, 2015; Brooks \& Brooks, 1994):

- Knowledge acquisition and understanding, which is the basis for creating new forms of thought;

- The disclosure of new knowledge in independent student activities;

- The expansion of the acquired knowledge boundaries in new conditions;

- The inventions/possible solutions to the problem with many alternative solutions.

The main idea in a constructivist approach is the student's thinking activity and the development of critical thinking. That requires a radical renewal of teaching methods and resources, and the teacher's ability to use diverse teaching techniques. It is very important for students to create an understanding of the succession and continuity of the learning process (Marshall, 1999). The learning process is structured in successive phases:

- Evocation - an offense phase in which students identify their previous knowledge, predict the knowledge and skills to be acquired, and set learning goals;

- Comprehension - is the phase in which students are looking for new knowledge and as a result of their actions, create their awareness and significance;

- Reflection - is a phase in which students look at the ideas learned and understand their meaning, ask questions, interpret, apply, discuss, test, and extend meaning by transferring it to other areas of activity. For the successful implementation of the system of principles, critical thinking offers innovative methodological solutions (Meredith et al., 2001).

Critical thinking and problem solving skills include the ability of individuals to a) reason effectively, b) ask pointed questions and solve problems, c) analyze and evaluate alternative points of view, and d) reflect critically on decisions and processes. Critical thinking focuses on the ability of learners to: a) 
reason effectively, b) use system thinking, c) make judgments and decisions, and solve problems (21st Century Skills for Students and Teachers, 2010).

Critical thinking is defined as the ability to analyze, interpret, evaluate, summarize, and synthesize information. What gives these, perhaps traditional, critical thinking skills a twist in the 21st Century is the availability of advanced technologies for accessing, manipulating, creating, analyzing, managing, storing, and communicating information (Fleming, 2018; Trilling \& Fadel, 2009).

\section{Materials and Methods}

The task for the project's first activity was to collect information of employers' needs for their staff competencies in design, technology and economics and elaborate recommendations for career counselors in service training program development. A questionnaire was used for data collection.

For the development of the questionnaire, profession standards from the Latvian Forestry and wood, Metal and machinery, and Agriculture and food sectors were analyzed as well as bachelor level graduates' competencies in design, technology and economics collected. The descriptions of the work processes were elaborated based on competencies from profession standards. The term of "competence" was not used in the questionnaire but the work process description was close to the description of competence given in professional standards. The questionnaire was elaborated in Latvian, then translated into English for discussion between partners and then translated to Estonian, Latvian and Lithuanian.

Data collection via the online questionnaire was conducted from January 12, 2017 till March 15, 2017. The questionnaire was delivered in Latvian, Lithuanian and Estonian languages. 130 questionnaires from the Forestry and wood, Metal and machinery, Agriculture and food sectors of industry were collected. Administrative, Sector managers and Sector specialists from each company voluntarily answered the questions online. Each respondent was invited to evaluate the relevance of the different work processes related to design, technologies and economics referring to his/her company activities and their future development. Fourteen work processes related to design, 31 work processes related to technologies and 21 work processes related to economics are included in the questionnaire. Each work process described in the questionnaire was marked with a 10 points scale, where 10 is "Very, very necessary" and 0 "necessary". Respondents answered questions from the perspective of his/her company or department (Erasmus + Strategic Partnership Project "Implementing Interdisciplinarity in Career Counselling”, 2017).

\section{Results}

Data analysis of the questionnaire and elaboration of recommendations for career counselors in the service training program development were done from March 15, 2017 till May 15, 2017. Work processes in Design, Technology and Economics were ranked by mean score in each selected Industrial sector - Forestry and wood, Metal and machinery, and Agriculture and food. We can see four high ranked work processes/competencies demanded by respondents in Table 1.

Results in Table 1 show that competences related to Design are more often repeated in all sectors of the industries. 11 from 12 competencies were repeated and just one competence not repeated in two other industry sectors. That lead to the conclusion to perceive four high ranked competences related to Design as more general.

Competences related to Technologies also repeated in all industries, but not as often as competences related to Design. 7 from 12 competences repeated and 5 are specific for their industrial sector. That leads to the conclusion that competences related to Technologies have similarities and differences.

Competences related to Economics repeated very rarely - just 3 of 12 competencies repeated in all industrial sectors. That lead to the conclusion to perceive competences related to Economics as more specific to their industrial sector. Probably the size of companies in different industries is different and that leads to specific competency demands. This data show just preliminary demand of competences and more data collection and analysis should be done in further future studies. 


\begin{tabular}{|c|c|c|c|c|c|c|}
\hline Industry & Design & & Technology & & Economic & \\
\hline \multirow[t]{4}{*}{$\begin{array}{l}\text { Wood- } \\
\text { Forestry }\end{array}$} & $\begin{array}{l}\text { Creative and independent } \\
\text { development of existing } \\
\text { and new products }\end{array}$ & 7.80 & $\begin{array}{l}\text { Forming a safe } \\
\text { workplace in } \\
\text { complying with fire } \\
\text { safety regulations in } \\
\text { the production } \\
\text { facility. }\end{array}$ & 8.96 & $\begin{array}{l}\text { Handling problem } \\
\text { situations } \\
\text { adequately and } \\
\text { timely adopting } \\
\text { necessary decisions. }\end{array}$ & 9.44 \\
\hline & $\begin{array}{l}\text { Navigating and managing } \\
\text { the used materials, to } \\
\text { analyse their improvement } \\
\text { and development trends, } \\
\text { and to be able to use them } \\
\text { at work }\end{array}$ & 7.73 & $\begin{array}{l}\text { Managing } \\
\text { technological } \\
\text { processes. }\end{array}$ & 8.630 & $\begin{array}{l}\text { Dealing with the } \\
\text { sector market. }\end{array}$ & 9.08 \\
\hline & $\begin{array}{l}\text { Creating long-term } \\
\text { products: which are } \\
\text { innovative, functional, } \\
\text { produced in a rational and } \\
\text { cheaper way, convenient } \\
\text { and easy to use, with } \\
\text { aesthetically high-quality } \\
\text { forms, colors, and textures. }\end{array}$ & 7.40 & $\begin{array}{l}\text { Adjustment of } \\
\text { production regimes } \\
\text { by applying } \\
\text { knowledge of } \\
\text { production } \\
\text { processes. }\end{array}$ & 8.630 & $\begin{array}{l}\text { Development of the } \\
\text { most cost-effective } \\
\text { technical solutions. }\end{array}$ & 8.88 \\
\hline & $\begin{array}{l}\text { Developing projects by } \\
\text { using computer-assisted } \\
\text { design and computer-aided } \\
\text { manufacturing } \\
\text { technologies. }\end{array}$ & 7.30 & $\begin{array}{l}\text { Making strategic } \\
\text { and operative } \\
\text { decisions by } \\
\text { summarizing and } \\
\text { analysing } \\
\text { production } \\
\text { information. }\end{array}$ & 8.56 & $\begin{array}{l}\text { Defining tasks in } \\
\text { achieving set } \\
\text { targets in order to } \\
\text { produce products } \\
\text { with high added } \\
\text { value. }\end{array}$ & 8.88 \\
\hline \multirow[t]{4}{*}{$\begin{array}{l}\text { Metal- } \\
\text { Machine } \\
\text { ry }\end{array}$} & $\begin{array}{l}\text { Developing of projects by } \\
\text { using computer-assisted } \\
\text { design and computer-aided } \\
\text { manufacturing } \\
\text { technologies. }\end{array}$ & 8.24 & $\begin{array}{l}\text { Choosing the most } \\
\text { rational technique } \\
\text { and technology. }\end{array}$ & 8.92 & $\begin{array}{l}\text { Handling problem } \\
\text { situations } \\
\text { adequately and } \\
\text { timely adopting } \\
\text { necessary decisions. }\end{array}$ & 9.04 \\
\hline & $\begin{array}{l}\text { Navigating and managing } \\
\text { used materials, to analyse } \\
\text { their improvement and } \\
\text { development trends, and to } \\
\text { be able to use them at work }\end{array}$ & 7.92 & $\begin{array}{l}\text { Developing } \\
\text { proposals which are } \\
\text { directed to more } \\
\text { efficient and useful } \\
\text { recourse utilization. }\end{array}$ & 8.84 & $\begin{array}{l}\text { Development and } \\
\text { management of } \\
\text { projects. }\end{array}$ & 8.84 \\
\hline & $\begin{array}{l}\text { Creative and independent } \\
\text { development of existing } \\
\text { and new products }\end{array}$ & 7.60 & $\begin{array}{l}\text { Adjustment of } \\
\text { production regimes } \\
\text { by applying } \\
\text { knowledge of } \\
\text { production process. }\end{array}$ & 8.600 & $\begin{array}{l}\text { Evaluating the } \\
\text { calculations of the } \\
\text { cost of services to } \\
\text { be performed, the } \\
\text { necessary } \\
\text { investments and } \\
\text { workforce } \\
\text { consumption. }\end{array}$ & 8.76 \\
\hline & $\begin{array}{l}\text { Creating long-term } \\
\text { product: which are } \\
\text { innovative, functional, } \\
\text { produced in a rational and } \\
\text { cheaper way, convenient } \\
\text { and easy to use, with } \\
\text { aesthetically high-quality } \\
\text { forms, colors, and textures. }\end{array}$ & 7.40 & $\begin{array}{l}\text { Managing the } \\
\text { production } \\
\text { technology of } \\
\text { Products and } \\
\text { Services. }\end{array}$ & 8.600 & $\begin{array}{l}\text { Using the necessary } \\
\text { technical and } \\
\text { normative } \\
\text { documentation for } \\
\text { the work, carrying } \\
\text { out applied and } \\
\text { professional } \\
\text { documents. }\end{array}$ & 8.68 \\
\hline $\begin{array}{l}\text { Agricult } \\
\text { ure-Food }\end{array}$ & $\begin{array}{l}\text { Navigating and managing } \\
\text { used materials, to analyse } \\
\text { their improvement and }\end{array}$ & 8.04 & $\begin{array}{l}\text { Using latest } \\
\text { information } \\
\text { technologies. }\end{array}$ & 8.00 & $\begin{array}{l}\text { Handling problem } \\
\text { situations } \\
\text { adequately and }\end{array}$ & 8.25 \\
\hline
\end{tabular}




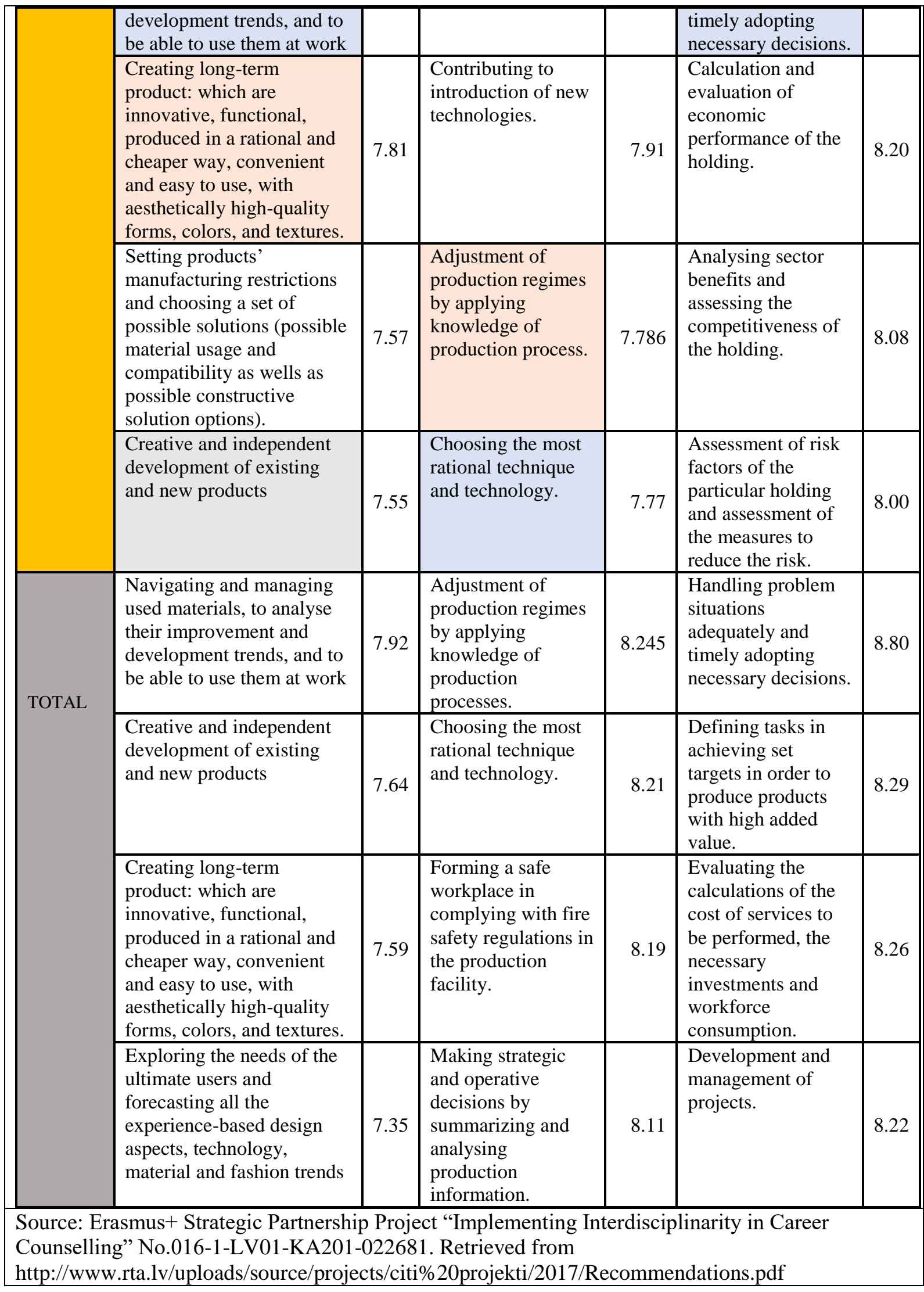

In these recommendation authors try to determine the general principles of how to connect guidance and secondary school students competencies development related to specific industrial The results give opportunity to connect demand for competencies in Design, Technologies and Economics with 
Teaching and Learning Strategies for the Critical Thinking three phases - Evocation/anticipation, Comprehension/the building knowledge, Reflection/consolidation (Crawford et al., 2005).

Evocation/anticipation phase is for the activation of imagination, prognosis, and to create interest. In this phase Career Counselor can base their activities during guidance on competencies related to Design as more general.

Comprehension/the building knowledge phase is for setting questions and finding answers. In this phase Career Counselor can lead students to inquire and base their activities during guidance on competencies related to Technologies.

Reflection/consolidation phase is for the reflection and personalization of findings and information. In this phase Career Counselor can ask students give personal responses based on competencies related to Economics.

All these stages can be implemented in different ways for each phase - problem based learning, group investigation, project, cooperative learning, etc. (Erasmus+ Strategic Partnership Project "Implementing Interdisciplinarity in Career Counselling", 2017).

\section{Conclusion}

This study determined the most demanded competencies in Wood-Forestry, Metal-Machinery, and Agriculture-Food industries related to design, technology and economics. The conclusion of this study is the recommendation to use a critical thinking approach to implement interdisciplinarity in career guidance in secondary schools. The career counselors should be introduced with the most demanded professional competencies in the Wood-Forestry, Metal-Machinery, Agriculture-Food industries during professional development training for career guidance in these industries at secondary school.

As next step is to implement interdisciplinarity in career guidance in secondary schools should be the elaboration of career counselors' professional development training program were critical thinking approach is on the base for introducing with competencies related to design, technology and economics in Wood-Forestry, Metal-Machinery and Agriculture-Food industries.

\section{References}

21 st Century Skills for Students and Teachers. (2010). Honolulu: Kamehameha Schools, Research \& Evaluation Division. Retrieved from http://www.ksbe.edu/_assets/spi/pdfs/21_century_skills_full.pdf

Boden, M. A. (2004). The Creative Mind: Myths and Mechanisms. London: Routledge.

Brooks, J. G., \& Brooks, M. G. (1994). In search of understandings: The case for constructivist classrooms. Alexandria: Association for Supervision and Curriculum Develoment.

Collin, A. (2009). Multidisciplinary, interdisciplinary, and transdisciplinary collaboration: implications for vocational psychology. International Journal for Educational and Vocational Guidance, 9(2), 101-110.

Crawford, A., Saul, W., Mathews, S., \& Makinster, J. (2005). Teaching and Learning Strategies for the Thinking Classroom. New York: International Debate Education Association. Retrieved from http://www.xaricidil.com/wpcontent/uploads/2017/07/Teaching-learning-strategies-for-the-thinking-classroom.pdf.

David, L. (2015). Constructivism. Learning Theories. Retrieved from https://www.learning-theories.com/constructivism.html Erasmus+ Strategic Partnership Project "Implementing Interdisciplinarity in Career Counselling” No.016-1-LV01-KA201022681. (2017). Retrieved from http://www.rta.lv/uploads/source/projects/citi\%20projekti/2017/Recommendations.pdf

Fleming, G. (2018). Introduction to Critical Thinking. Retrieved from https://www.thoughtco.com/introduction-to-criticalthinking-1857079

Karjeras izglītība skolā [Career Education at School]. (2010). Rīga: Valsts izglīitības attīstības aǵentūra, Retrieved from http://viaa.gov.lv/files/news/727/karjeras_izgliitiiba_skolaa_2010.pdf.

Kenneth, B. H. (2001). Career Education and Education Reform: Time for a Rebirth. Phi Delta Kappan International, 83(4), 327-331. Retrieved from http://journals.sagepub.com/doi/pdf/10.1177/003172170108300413

Marshall, N. (1999). The Students. Who are they and how do I reach them? Reading and writing for critical thinking, 5(3), 45-47.

Meredith, K. S., Steele, J. L., \& Kikusova, S. (2001). Critical Issues: Democracy, Community, Self, Literacy, and the Value of Global Conversation. Journal of Literacy Research, 33(1), 169-202.

Rethinking Education: Investing in skills for better socio-economic outcomes. (2012). Strasbourg: European Comission. Retrieved from file:///C:/Users/user/Downloads/com669_en.pdf

Trilling \& Fadel (2009). 21st Century Learning Skills. San Francisco, CA: John Wiley \& Sons. 